\title{
Effect of clay mixing, irrigation and sulphur on growth and yield of fenugreek on loamy sand soil (Trigonella foenum-graecum L.)
}

\section{RAMKISHOR, H.P. VERMAAND B.L. KUMAWAT}

Received : 28.10.2014; Revised : 08.04.2015; Accepted : 16.04 .2015

\section{MEMBERS OF RESEARCH FORUM:}

Corresponding author: RAMKISHOR, Department of Soil Science, S.K.N. College of Agriculture, JOBNER (RAJASTHAN) INDIA

Email: hppersoya.p@gmail.com

Co-authors :

H.P. VERMA, Department of Agronomy, College of Agriculture, S.K.N. Agriculture University, JOBNER (RAJASTHAN) INDIA

B.L. KUMAWAT, Department of Soil Science, S.K.N. College of Agriculture, JOBNER (RAJASTHAN) INDIA

\begin{abstract}
Summary
A field experiment on effect of clay mixing, irrigation and sulphur on growth and yield of fenugreek (Trigonella foenum- graecum L.) on loamy sand soil, was conducted at S.K.N. College of Agriculture, Jobner (Rajasthan) during Rabi seasons 2006-07 and 2007-08. The experiment consisted of 36 treatment combinations of 3 levels of clay mixing $(0,1$ and $2 \%), 3$ levels of irrigation [ 4 application of irrigation at lateral bud initiation (LBI) + flower initiation $(\mathrm{FI})+$ pod initiation (PI) + grain development (GD), 6 application of irrigation at LBI + PI and 8 irrigations applied at all the phenological stages of crop growth (LBI + branching + FI + full flowering + PI + pod enlargement and grain formation + GD + ripening] as main plot treatments and 4 levels of sulphur (0,20, 40 and $60 \mathrm{~kg} \mathrm{~S} / \mathrm{ha}$ through gypsum) as sub plot treatments was laid out in split plot design with three replications. The results indicated that application of clay @ 2 per cent gave significantly higher growth, yield attributes and yield and remained at par with application of clay @ 1 per cent in both the year as well pooled mean over control. The results further indicate that application of 8 irrigation resulted in significantly higher growth, yield attributes and yield and remained at par with the application of 6 irrigation in pods per plant and seeds per pods in both the years as well as pooled mean over the control. The application of sulphur @ $40 \mathrm{~kg} / \mathrm{ha}$ gave significantly higher the growth, yield attributes and yield in pooled mean basis over rest of treatments.
\end{abstract}

Key words : Clay, Fenugreek, Growth, Irrigation, Sulphur, Yield

How to cite this article : Ramkishor., Verma, H.P. and Kumawat, B.L. (2015). Effect of clay mixing, irrigation and sulphur on growth and yield of fenugreek on loamy sand soil (Trigonella foenum- graecum L.). Asian J. Soil Sci., 10(1) : 29-33. 